\title{
PENGARUH PENAMBAHAN BEESWAX DAN GLISEROL TERHADAP KARAKTERISTIK POLIBLEND GLUKOMANAN - POLIVINIL ALKOHOL (PVA)
}

\author{
Sari Purnavita* dan Ayu Anggraeni \\ Program Studi D III Teknik Kimia, Politeknik Katolik Mangunwijaya \\ *Email: Saripurnavita@yahoo.com
}

\begin{abstract}
Abstrak
Poliblend glukomanan-PVA dengan penambahan beeswax dan gliserol berpotensi menjadi alternatif bahan pengemas biodegradable. Pada penelitian ini, gliserol dan beeswax ditambahkan pada poliblend glukomanan-PVA rasio 1:2, diikuti pemanasan suhu $80^{\circ} \mathrm{C}$ selama 30 menit. Tujuan dari penambahan beeswax dan gliserol adalah untuk memperbaiki karakteristik poliblend yang dihasilkan. Oleh karena itu, pada penelitian ini dipelajari pengaruh penambahan beeswax (0g;0.03g;0.06g;0.09g;0.12g) dan gliserol $(5 \mathrm{ml}, 10 \mathrm{ml}, 15 \mathrm{ml})$ terhadap karakteristik film kemasan meliputi ketebalan, kuat tarik, kemuluran, laju transmisi uap air, presentase kelarutan dalam air dan morfologi. Dari hasil penelitian diperoleh ketebalan film kemasan terbaik pada penambahan beeswax 0.12 gram dan gliserol $15 \mathrm{ml}$. untuk hasil uji kuat tarik dan persen elongasi terbaik pada penambahan beeswax 0.06 gram dan gliserol 5ml. Pada uji permeabilitas uap air hasil terbaik diperoleh pada penambahan beeswax 0,12 gram dan gliserol $5 \mathrm{ml}$, untuk hasil presentase kelarutan dalam air terbaik diperoleh pada penambahan beeswax 0.12 gram dan $5 \mathrm{ml}$ gliserol.
\end{abstract}

Kata kunci : Film kemasan, beeswax, gliserol, poliblend, glukomanan, PVA

\section{PENDAHULUAN}

Produk pangan merupakan produk yang mudah mengalami kerusakan, karena proses kimia dalam bahan, mikrobiologi dan faktor fisik (Muranyi, 2013). Untuk melindungi produk dari kerusakan, produk biasanya diberi kemasan. Sebagian besar kemasan yang digunakan saat ini, tidak dapat atau sulit terurai secara alami (non-biodegradable), yang menyebabkan pencemaran lingkungan. Oleh karena itu, diperlukan alternatif penggunaan bahan pembuat kemasan yang bersifat biodegradable.

Kemasan biodegradable merupakan kemasan yang dapat hancur secara alami. Menurut Pranamuda (2003), plastik biodegradable adalah plastik yang terurai oleh aktivitas mikroorganisme menjadi hasil akhir air dan gas karbondioksida. Syarat film kemasan yaitu bersifat fleksibel, mampu menghambat keluar masuknya gas dan uap air, serta dapat dihancurkan secara alami maupun mikrobiologis (Paramawati, 2007).

Glukomanan dapat dimanfaatkan sebagai bahan pembuatan film kemasan karena dapat membentuk struktur serat-serat halus (Irsani, 2016). Film kemasan yang dibuat dari glukomanan saja memiliki sifat mudah sobek, sehingga perlu ditambahan plasticizer untuk meningkatkan elastisitas, mengurangi resiko mudah sobek dan hancurnya film kemasan.
Gliserol mampu menurunkan gaya intermolekuler sepanjang rantai polimer, dan menyebabkan film dari polisakarida akan lentur (Rodriguez et al., 2006). Gliserol mudah larut dalam air (hidrofilik) sehingga sesuai untuk bahan pembentuk film dari polisakarida (Krisna, 2011). Bentuk cair gliserol lebih menguntungkan karena proses pencampuran dengan bahan lain lebih mudah (Anker, et al., 2000).

Semakin banyak gliserol yang ditambahkan, fleksibilitas dan permeabilitas suatu film kemasan akan meningkat. Hal ini tidak sesuai dengan persyaratan kemasan yang baik, dengan semakin tinggi nilai permeabilitas, maka kemasan dianggap tidak mampu melindungi produk secara maksimal dari pengaruh uap air, oksigen, dan karbondioksida yang memicu terjadinya kerusakan pada produk.

Beeswax merupakan komponen lipid yang dapat digunakan untuk menurunkan permeabilitas suatu film kemasan. Pemilihan bahan didasarkan kemudahan terdegradasi, harga relatif murah, dan mudah diperoleh.

Penelitian ini dilakukan menggunakan Rancangan Acak Lengkap (RAL) faktorial dengan dua variable, yaitu massa beeswax yang terdiri dari 5 jenis perlakuan., dan volume gliserol yang terdiri dari 3 jenis perlakuan, dengan dua kali ulangan Pada penelitian ini, parameter yang diukur meliputi ketebalan film, 
kelarutan dalam air, transmisi uap air, tensile strength, persen elongasi dan morfologi.

\section{METODOLOGI}

Bahan utama yang digunakan pada penelitian ini adalah tepung glukomanan, gliserol, PVA, dan beeswax. Alat yang digunakan yaitu: gelas ukur, plat plastik, hot plate, magnetic stirer, pengaduk, oven, termometer, ayakan, neraca analitik, beaker glass, gelas arloji, cawan dan makrometer

Pada bagian awal, 6 gram PVA dilarutkan dalam $100 \mathrm{ml}$ aquades, dipanaskan pada suhu $70^{\circ} \mathrm{C}$. Pada tempat lain 3 gram glukomanan dilarutkan dalam $200 \mathrm{ml}$ aquades, kemudian disaring untuk mendapatkan filtrat. Setelah PVA larut, kemudian ditambahkan glukomanan, gliserol, dan beeswax sambil dipanaskan hingga suhu $80^{\circ} \mathrm{C}$. Kemudian ukur volume larutan $200 \mathrm{ml}$ dan tuang pada cetakan. Lakukan pengeringan pada suhu $60^{\circ} \mathrm{C}$ selama 24 jam, selanjutnya melakukan pengamatan karakteristik film kemasn.

\section{Penentuan Ketebalan Film}

Ketebalan diukur dengan menggunakan mikrometer. Ketebalan diukur pada 5-7 titik yang berbeda

\section{Penentuan presentase kelarutan dalam air}

Sampel dipotong dengan ukuran $2 \times 2 \mathrm{~cm}$, diletakkan dalam cawan alumunium yang terlebih dahulu sudah dikeringkan dan ditimbang beratnya. Sampel film dimasukkan ke dalam oven dengan suhu $100^{\circ} \mathrm{C}$, selama 30 menit. Timbang berat sampel kering sebagai berat kering awal (wo), kemudian sampel direndam selama 20 jam dalam $10 \mathrm{ml}$ aquades. Persentase kelarutan sampel dalam air (S) dihitung dengan persamaan:

$$
\mathrm{S}=\mathrm{w}_{0}-\mathrm{w}_{1} \times 100 \%
$$

\section{Pengukuran laju transmisi uap air}

Laju transmisi uap air (WVTR) ditentukan secara gravimetri dengan memodifikasi metode yang dikemukakan oleh $\mathrm{Xu}$ et al. (2005). Sampel film yang akan diuji ditutupkan pada cawan yang didalamnya berisi 3 gram silika gel, dan selanjutnya ditempatkan dalam wadah yang berisi larutan garam $\mathrm{NaCl} 20 \%$ (b/v) $(\mathrm{RH}$ $=75 \%$ ). Uap air yang terdifusi melalui film diserap oleh silika gel sehingga menambah beratnya. Berat cawan dicatat setiap jam selama 6 pengamatan. Data yang diperoleh dibuat persamaan regresi linier, dan ditentukan slopenya. Laju transmisi uap air ditentukan dengan persamaan:

$$
W V T R=\frac{\text { slope kenaikanberat vawau[g/jam] }}{\text { luarpermukaan tilm }(\mathrm{m} 2]}
$$

\section{Pengukuran kadar air}

Sampel ditimbang sebanyak 2-5 gram pada cawan porselin. Cawan tersebut dimasukkan ke dalam oven selama 5 jam pada suhu $100{ }^{\circ} \mathrm{C}-$ $105{ }^{\circ} \mathrm{C}$ atau sampai beratnya menjadi konstan. Kehilangan berat tersebut dihitung sebagai presentase kadar air dan dihitung dengan rumus Kadiar uir $=\frac{\text { mussu awal }- \text { mussu konstan }}{\text { mussu awal }} \times 100 \%$

\section{Penentuan Tensile Strength dan Persen Elongasi}

Untuk mengetahui tensile strength dan elongasi film dilakukan dengan menggunakan alat Imada Force Measurement tipe ZP-200N. Rumus untuk menghitung tensile strength dan persen elongasi film kemasan :

$$
\text { Tensile strengLh }\left(\mathrm{N} / \mathrm{cm}^{2}\right)-\frac{\text { Gaya }}{\text { Satuan Luns }\left(\mathrm{cm}^{2}\right)}
$$

$$
\text { tilongasi }(\%)-\underset{P \text { erponjangan edible film }(\mathrm{cm})}{\text { Punjung awal edible film }} \times 1000 \%
$$

\section{Pengamatan Morfologi Film Kemasan}

Permukaan sampel diamati menggunakan mikroskop. Sampel diambil beberapa bagian kecil lalu diletakkan di kaca preparat dan diamati permukaannya dengan mengatur perbesaran pada mikroskop sehingga bentuk permukaan sampel dapat teramati dengan baik.

\section{HASIL DAN PEMBAHASAN}

\section{a. Hasil Ketebalan Film Kemasan}

Pada percobaan ini, didapatkan hasil pada variable gliserol $5 \mathrm{ml}$ optimal di penambahan beeswax sebanyak 0,12 gram yaitu ketebalan plastik 0,246 cm. Pada penambahan $10 \mathrm{ml}$ giserol di dapatkan ketebalan kemasan optimal dengan penambahan beeswax sebanyak 0,12 gram yaitu $0,254 \mathrm{~cm}$. Sedangkan pada penambahan gliserol $15 \mathrm{ml}$ didapatkan ketebalan yang optimal pada penambahan beeswax 0,12 gram yaitu 0,264 $\mathrm{cm}$. Dengan data diatas dapat disimpulkan bahwa hasil terbaik pada penambahan beeswax sebanyak 0,12 gram dengan penambahan gliserol 
sebanyak $15 \mathrm{ml}$, hal ini dapat dilihat pada Gambar 1.

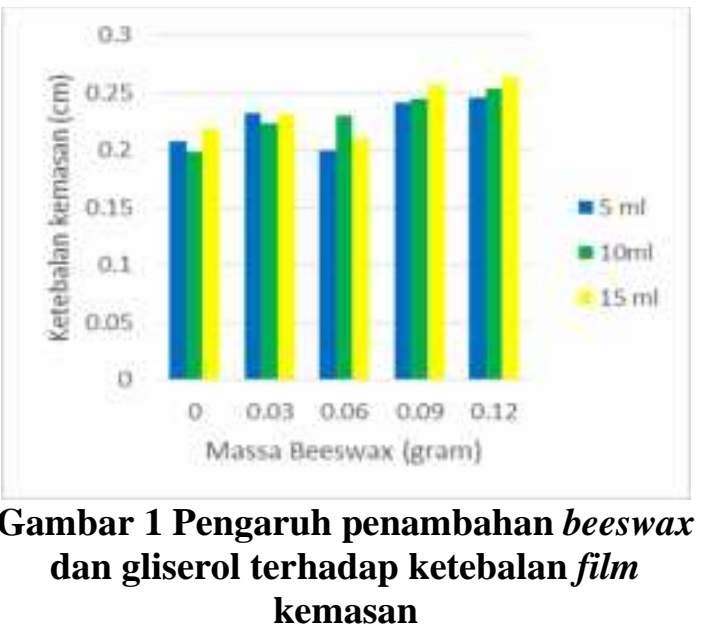

Berdasarkan grafik pada gambar 1 semakin banyak bahan yang ditambahkan maka ketebalan film akan meningkat. Berdasarkan analisa ANNOVA yang dilakukan, penambahan massa beeswax berpengaruh nyata terhadap ketebalan plastik yang di hasilkan. Pada Gambar 1 selaras dengan penelitian yang telah dilakukan Sumarto (2008) dimana ketebalan film dipengaruhi oleh banyaknya total padatan dalam larutan, ketebalan (tinggi) cetakan dan volume larutan. Pada grafik gambar 1 dapat disimpulkan bahwa penambahan beeswax dan gliserol berpengaruh terhadap ketebalan kemasan. Semakin tinggi total padatan di dalam campuran maka ketebalan kemasan juga semakin tinggi. Ketebalan merupakan parameter yang berpengaruh terhadap penggunaan film sebagai pengemas, semakin tebal film yang dihasilkan maka semakin baik kemampuan pengemas untuk melindungi produk.

\section{b. Hasil tensile strength film kemasan}

Pengujian kuat tarik dilakukan untuk mengetahui ketahanan film kemasan terhadap tarikan maksimal sebelum film putus atau sobek. Pada percobaan ini, didapatkan hasil kuat tarik pada variable gliserol $5 \mathrm{ml}$ optimal di penambahan beeswax sebanyak 0,06 gram sebesar $0,46 \mathrm{~kg} / \mathrm{mm}^{2}$. Pada penambahan $10 \mathrm{ml}$ giserol di dapatkan kuat tarik optimal dengan penambahan beeswax sebanyak 0,06 gram sebesar $0,21 \mathrm{~kg} / \mathrm{mm}^{2}$. Sedangkan pada penambahan gliserol $15 \mathrm{ml}$ didapatkan kuat tarik yang optimal pada penambahan beeswax 0,06 gram sebesar $0,14 \mathrm{~kg} / \mathrm{mm}^{2}$. Dengan data diatas dapat disimpulkan bahwa hasil terbaik pada penambahan beeswax sebanyak 0,06 gram dengan penambahan gliserol sebanyak $5 \mathrm{ml}$, hal ini dapat dilihat pada Gambar 2.

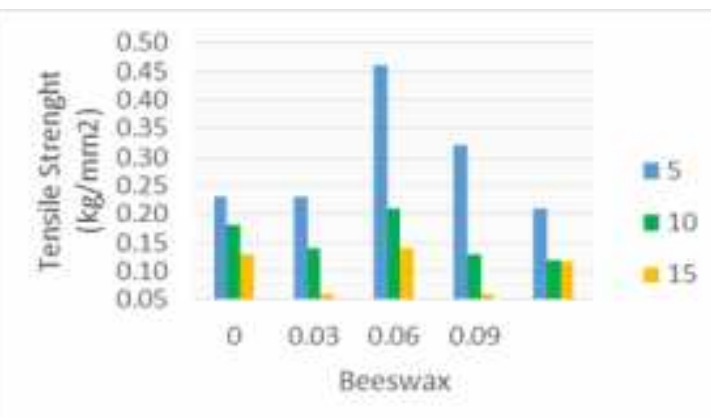

\section{Gambar 2. Pengaruh penambahan beeswax dan gliserol terhadap tensile strength film kemasan}

Berdasarkan grafik pada gambar 2, adanya penambahan variasi jumlah gliserol $(5 \mathrm{ml} ; 10$ $\mathrm{ml}$; dan $15 \mathrm{ml}$ ) pada titik variable beeswax 0 gram menunjukkan grafik menurun. Hal ini sesuai dengan penelitian yang telah dilakukan Sari (2008) dikatakan bahwa semakin banyak jumlah gliserol yang ditambahkan maka kuat tarik suatu kemasan semakin menurun. Hal ini terjadi karena kuat tarik kemasan berkaitan dengan kadar air, dimana jumlah gliserol yang meningkat juga mengakibatkan kenaikan kadar air yang terkandung di kemasan plastik.

Kadar air yang semakin meningkat akan menyebabkan kemasan tersebut semakin tidak elastis dan mudah rapuh karena air mengakibatkan pengurangan kekuatan antar molekul. Kekuatan antar molekul pada film kemasan yang semakin menurun mengakibatkan film kemasan tidak elastis, sehingga kuat tarik yang dihasilkan akan semakin menurun (Harris, 1999). Gliserol mengurangi ikatan hidrogen yang menyebabkan jarak antar molekul semakin merenggang sehingga kekuatan film akan berkurang (Mc Hugh et al., 1994).

Berdasarkan grafik di gambar 2 menunjukkan pada variasi penambahan gliserol $(5 \mathrm{ml}, 10 \mathrm{ml}$, dan $15 \mathrm{ml})$ dengan penambahan beeswax 0,06 gram merupakan hasil yang optimal. Sedangkan pada penambahan beeswax sebesar 0,09 gram dan 0,12 gram film kemasan mengalami penurunan kuat tarik. Hasil ini selaras dengan penelitian yang telah dilakukan oleh Herawan (2015) yang menyatakan bahwa konsentrasi lilin lebah (beeswax) yang tinggi menurunkan nilai kuat tarik dari produk edible film pektin pisang, karena beeswax merupakan 
lipid yang tidak larut dalam air pada pembuatan film sehingga ikatan yang terjadi tidak terbentuk dengan baik dan menurunkan nilai kuat tarik produk.

Berdasarkan gambar 2, hasil tensile strength tertinggi pada variasi penambahan beeswax 0.06 gram dan gliserol $5 \mathrm{ml}$, pada penambahan ini ikatan yang terjadi antara beeswax, gliserol dengan materi lain berlangsung dengan baik membentuk permukaan rapat sehingga menghasilkan tensile strength yang tinggi.

\section{c. Hasil Elongasi Film Kemasan}

Pada percobaan ini, didapatkan hasil pada variable gliserol $5 \mathrm{ml}$ presentase elongasi optimal di penambahan beeswax sebanyak 0,06 gram sebesar $484 \%$. Pada penambahan $10 \mathrm{ml}$ gliserol di dapatkan hasil elongasi optimal dengan penambahan beeswax sebanyak 0,03 gram sebesar 393\%. Sedangkan pada penambahan gliserol $15 \mathrm{ml}$ didapatkan hasil elongasi optimal pada penambahan beeswax 0,06 gram sebesar $341 \%$. Dengan data diatas dapat disimpulkan bahwa hasil terbaik pada penambahan beeswax sebanyak 0,06 gram dengan penambahan gliserol sebanyak $5 \mathrm{ml}$, hal ini dapat dilihat pada Gambar 3.

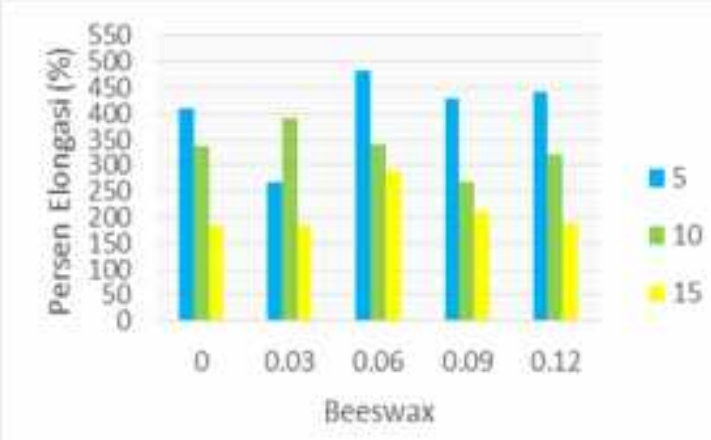

Gambar 3. Pengaruh penambahan beeswax dan gliserol terhadap persen elongasi film kemasan

Pengujian elongasi film kemasan dilakukan dengan orientasi machine direction Hasil persen elongasi berbanding terbalik dengan tensile strength, dengan semakin besar nilai tensile strength maka semakin kecil nilai elongasi yang di dapat. Sun et al (2008) menerangkan bahwa nilai elongasi akan semakin meningkat seiring dengan peningkatan dosis pemlastis. Namun hasil pengujian menunjukkan hal yang sebaliknya dimana nilai elongasi film kemasan mengalami penurunan seiring dengan meningkatnya volume penambahan gliserol.
Hal ini terjadi diduga karena kurang homogennya proses pencampuran sehingga bahan pemlastis tidak terdistribusi sempurna dalam komposit film kemasan dan berdampak pada penurunan persen elongasi film.

Berdasarkan grafik pada gambar 3 menunjukkan penambahan gliserol $5 \mathrm{ml}$ dan beeswax 0,06 gram menghasilkan persentase elongasi tertinggi, sehingga dapat disimpulkan pada formulasi ini ikatan yang terjadi antara gliserol, glukomanan, dan beeswax berlangsung dengan baik dan menghasilkan kerapatan film yang fleksibel. Berdasarkan analisa ANNOVA, adanya kombinasi perlakuan penambahan beeswax dan gliserol berpengaruh sangat nyata terhadap persen elongasi film kemasan yang dihasilkan.

\section{d. Hasil Water Vapour Transmission Rate Film Kemasan}

Laju permeabilitas uap air (WVTR) merupakan salah satu sifat penting yang menunjukkan ketahanan suatu film dalam menjaga kandungan uap air dari bahan yang dikemas. Pada percobaan ini, didapatkan hasil laju transmisi uap air pada variable gliserol 5 $\mathrm{ml}$ optimal di penambahan beeswax sebanyak 0,12 gram sebesar 2,78 $\mathrm{g}^{2} / \mathrm{m}^{2}$ jam. Pada penambahan $10 \mathrm{ml}$ gliserol di dapatkan hasil laju transmisi uap air optimal dengan penambahan beeswax sebanyak 0,12 gram sebesar $6,0 \mathrm{~g}^{2} / \mathrm{m}^{2}$ jam.

Sedangkan pada penambahan gliserol $15 \mathrm{ml}$ didapatkan hasil laju transmisi uap air optimal pada penambahan beeswax 0,12 gram sebesar $8,70 \mathrm{~g}^{2} / \mathrm{m}^{2} \mathrm{jam}$. Dengan data diatas dapat disimpulkan bahwa hasil terbaik pada penambahan beeswax sebanyak 0,12 gram dengan penambahan gliserol sebanyak $5 \mathrm{ml}$, hal ini dapat dilihat pada Gambar 4.

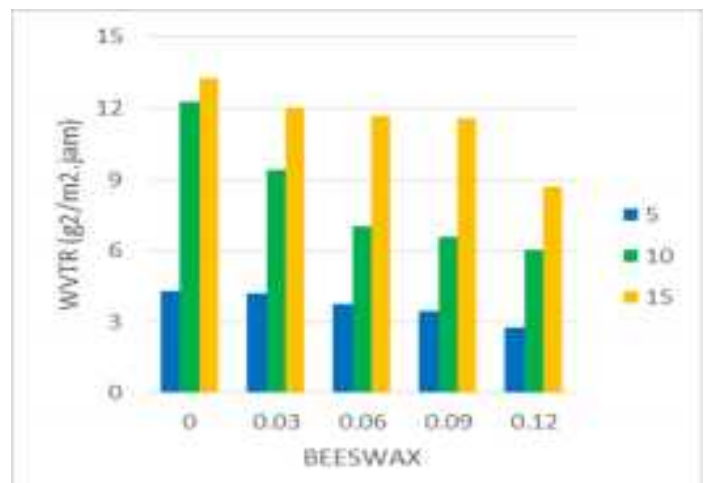

Gambar 4. Pengaruh penambahan beeswax dan gliserol terhadap laju permeabilitas uap air film kemasan 
Berdasarkan grafik pada gambar 4 pada penambahan beeswax 0 gram dengan variasi penambahan gliserol $(5 \mathrm{ml}, 10 \mathrm{ml}$, dan $15 \mathrm{ml})$ menunjukkan grafik yang meningkat dengan hasil laju transmisi uap air semakin besar. Hal ini disebabkan karena laju transmisi uap air berhubungan dengan sifat hidrofilik gliserol. Hal ini sejalan dengan penelitian yang telah dilakukan Ningsih (2015) gliserol memiliki kemampuan yang tinggi dalam mengikat air sehingga menghasilkan nilai laju transmisi uap air yang tinggi.

Plasticizer gliserol akan menyebabkan penurunan ikatan hidrogen internal dan peningkatan jarak intermolekuler yang memudahkan perpindahan molekul uap air. Lebih lanjut menurut McHugh dan Krochta, (1994) film kemasan dengan plasticizer gliserol memiliki nilai permeabilitas atau ketahanan uap air yang rendah.

Berdasarkan grafik pada gambar 4 pada penambahan gliserol $5 \mathrm{ml}, 10 \mathrm{ml}$, dan $15 \mathrm{ml}$ dengan variasi penambahan beeswax $(0 \mathrm{~g}$; $0,03 \mathrm{~g} ; 0,06 \mathrm{~g} ; 0,09 \mathrm{~g} ; 0,12 \mathrm{~g}$ ) menunjukkan grafik yang menurun, dengan hasil laju transmisi uap air semakin kecil. Hasil penelitian ini selaras dengan penelitian yang telah dilakukan oleh Noviyanti (2014) dimana semakin banyak konsentrasi lilin lebah yang ditambahkan pada film, nilai permeabilitas uap air pada film semakin menurun. Lilin lebah berfungsi menahan laju transmisi uap air. Pada waktu pengeringan, lilin lebah membentuk jaringan kristal yang berfungsi sebagai penahan uap air. Lebih lanjut menurut Deberaufort (1993) laju transmisi uap air akan menurun dengan meningkatnya sifat hidrofobik dari senyawa penyusun film.

Berdasarkan grafik pada gambar 4 dan analisa ANNOVA, adanya kombinasi perlakuan penambahan gliserol dan beeswax berpengaruh sangat nyata terhadap laju transimi uap air pada film kemasan. Dengan kondisi terbaik pada penambahan beeswax 0.12 gram dan gliserol 5 ml. Pada kondisi ini, hasil laju transmisi air kecil sehingga semakin baik suatu film kemasan tersebut apabila diaplikasikan sebagai bahan pengemas karena semakin sedikit uap air yang dapat menembus ke dalam film dan tidak menyebabkan kadar air bahan yang dikemas meningkat.

\section{e. Hasil presentase kelarutan dalam air}

Pada percobaan ini, didapatkan presentase kelarutan dalam air pada variable gliserol $5 \mathrm{ml}$ optimal di penambahan beeswax sebanyak 0,12 gram sebesar 27\%. Pada penambahan $10 \mathrm{ml}$ gliserol di dapatkan hasil presentase kelarutan dalam air optimal dengan penambahan beeswax sebanyak 0,12 gram sebesar $38,10 \%$.

Sedangkan pada penambahan gliserol $15 \mathrm{ml}$ didapatkan hasil presentase kelarutan dalam air optimal pada penambahan beeswax 0,12 gram sebesar $52,27 \%$. Dengan data diatas dapat disimpulkan bahwa hasil terbaik pada penambahan beeswax sebanyak 0,12 gram dengan penambahan gliserol sebanyak $5 \mathrm{ml}$, hal ini dapat dilihat pada Gambar 5.

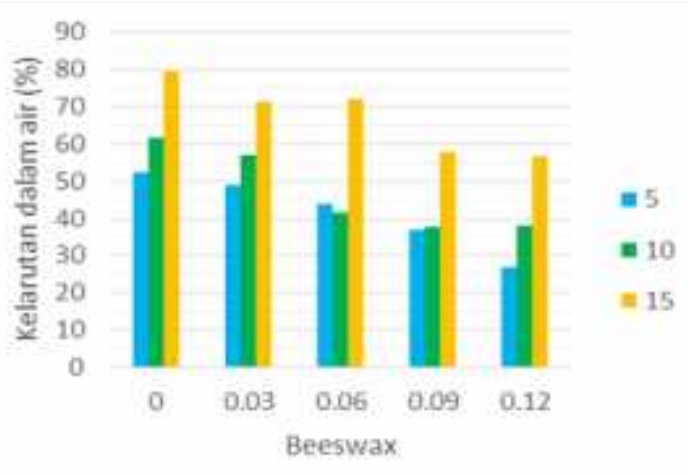

\section{Gambar 5. Pengaruh penambahan beeswax dan gliserol terhadap kelarutan film kemasan dalam air}

Berdasarkan grafik pada gambar 5 dengan penambahan beeswax 0 gram dan variasi penambahan gliserol $(5 \mathrm{ml}, 10 \mathrm{ml}, 15 \mathrm{ml})$ menunjukkan grafik yang meningkat dengan hasil kelarutan film kemasan dalam air semakin besar. Hasil penelitian ini sesuai dengan penelitian yang telah dilakukan Anandito, dkk (2012) yang menyatakan bahwa adanya penambahan gliserol secara nyata mampu meningkatkan kelarutan film. Hal ini dikarenakan gliserol bersifat hidrofilik yaitu mudah larut dalam air sehingga dapat meningkatkan persentase kelarutan dari suatu film kemasan. Lebih jauh menurut Anandito, dkk (2012) semua bahan yang ditambahkan dalam komposit film kemasan yang bersifat hidrofilik akan menyebabkan peningkatan persentase kelarutan film, termasuk glukomanan.

Berdasarkan grafik pada gambar 5 pada penambahan gliserol dengan volume $5 \mathrm{ml}, 10$ $\mathrm{ml}$, dan $15 \mathrm{ml}$ dengan variasi penambahan massa beeswax (0 gram; 0,03 gram; 0,06 gram; 0.09 gram; dan 0,12 gram) menunjukkan grafik yang menurun dengan hasil kelarutan film 
kemasan dalam air akan semakin kecil. Hal ini berkaitan dengan sifat hidrofobik beeswax yang cenderung lebih sulit untuk bercampur atau larut dalam air. Kelarutan merupakan tolak ukur ketahanan suatu film ketika digunakan untuk pengemasan.

Berdasarkan grafik pada gambar 5 dan analisis ANNOVA, adanya kombinasi perlakuan beeswax dan gliserol berpengaruh nyata terhadap presentase kelarutan film kemasan dalam air, dengan kondisi perlakuan terbaik pada penambahan beeswax 0.12 gram dan gliserol $5 \mathrm{ml}$

\section{KESIMPULAN}

a. Nilai ketebalan film kemasan tertinggi pada formulasi penambahan beeswax 0,12 gram dan gliserol $15 \mathrm{ml}$, dengan nilai tensile strength $0.12 \mathrm{~kg} / \mathrm{mm}^{2}$ dan persen elongasi $190 \%$

b. Nilai tensile strength dan persen elongasi tertinggi pada formulasi penambahan beeswax 0.06 gram dan gliserol $5 \mathrm{ml}$, dengan nilai tensile strength $0.46 \mathrm{~kg} / \mathrm{mm}^{2}$ dan persen elongasi $484 \%$

c. Nilai laju permeabilitas uap air film kemasan terendah pada formulasi penambahan beeswax 0.12 gram dan gliserol $5 \mathrm{ml}$ dengan nilai tensile strength $0.21 \mathrm{~kg} / \mathrm{mm}^{2}$ dan persen elongasi $442 \%$

d. Presentase kelarutan film kemasan terendah yaitu pada penambahan beeswax 0.12 gram dan gliserol $5 \mathrm{ml}$ dengan nilai tensile strength $0.21 \mathrm{~kg} / \mathrm{mm}^{2}$ dan persen elongasi $442 \%$

\section{DAFTAR PUSTAKA}

Anandito, R, Nurhartadi dan Akhmad. 2012. Pengaruh gliserol terhadap karakteristik edible film berbahan dasar tepung jali (Coix lacryma-jobi L.). Jurnal Teknologi Hasil Pertanian, Vol. V, No. 2, Februari 2012

Anker, M., Mats, S., and Anne-Marie,H., 2000. Relationship between the Microstructure and the Mechanical and Barrier Properties of Whey Protein Films. $J$. Agric. Food Chem, Vol. 48 : 3806-3816.

Debeaufort F, Martin Polo M, dan Volley. 1993. Polarity Homogenity and Structure Affect Water Vapour Permeability of Model Edible Film. J Food Sci. 58:426434.

Haris, H. 1999. Kajian Teknik Formulasi Terhadap Karakteristik Edible Film dari
Pati Ubi Kayu, Aren, dan Sagu Untuk Pengemas Produk Pangan Semi Basah. Disertasi Program Dokter Ilmu-ilmu Pertanian Program Pascasarjana Institut Pertanian Bogor.

Herawan, C.D. 2015. Sintesis dan karakteristik edible film dari pati kulit pisang dengan penambahan lilin lebah (beeswax). Skripsi. FMIPA UNNES Semarang

Irsani, I. N. 2016. Glukomanan Umbi Suweg (Amorphophallus Campanulatus B) Sebagai Inhibitor Enzime $\alpha$ - Amilase Skripsi. Malang : Akademi Analis Farmasi Putra Indonesia Malang

Krisna, Adi. 2011. Pengaruh Regelatinasi Dan Modifikasi Hidrotermal Terhadap Sifat Fisik Pada Pembuatan Edible Film Dari Pati Kacang Merah (VignaAngularis Sp.). Thesis. Semarang : UNDIP

McHugh, T. H dan Krochta, J.M. 1994. Permeability Properties of Edible Film. Di dalam Krochta, J.M., E.A. Baldwin and M.O Nisperos Carriedo. Edible Coating and Film to Improve Quality. Technomic Publising Co. Inc, Pensylvenia.

McHugh, T,R, and Krochta, J,M. 1994. Dispersed phase particle size effects on water vapor permeability of whey protein-beeswax edible emulsion films, $J$, Food Process, Pres, , 18, pp, 173-188

McHugh, T,H, Aujard, J,F, and Krochta,J, M. 1994. Plasticized whey protein edible films: water vapor permeability properties. Journal of food science 59;416- 419 .

Muranyi,P 2013. Functional Edible Coating for Fresh Food Products. J. Food Process. Technol, 4(1), e114

Ningsih, S. 2015.Pengaruh plasticizer gliserol terhadap karakteristik edible film campuran whey dan agar. Skripsi. Fakultas peternakan Universitas Hasanuddin Makassar

Noviyanti.2014. Bioplastik komposit pati tapioka dan lilin Lebah dengan tambahan natrium alginate Sebagai pengemulsi. Skripsi. FMIPA Institut Pertanian Bogor

Paramawati, R, Wijaya dan Suminar. 2007. Evaluasi Ciri Mekanis dan Fisis Bioplastik dari campuran Poli Asam Laktat dan Polisakarida. Jurnal Ilmu Pertanian Indonesia. Vol 12 No $2 \mathrm{hlm}$ 75-83 
Pranamuda, H. 2003. Pengembangan Bahan Plastik Biodegradable Berbahan baku Pati Tropis. Hasil Penelitian dari BPPT

Rodriguez, M, J, Oses, K, Ziani, and J,I, Mate. 2006. Combined effect of plasticizers and surfactants on the physical properties of starch based edible films. Food Res. Int. 39: $840-846$

Sari, T, Manurung dan Fery. 2008. Pembuatan Edible dari Kolang Kaling. Jurnal Teknik Kimia. No 4. Vol 15 Desember 2008

Sumarto. 2000. Mempelajari Pengaruh Penambahan Asam Lemak dan Natrium Benzoat terhadap Sifat Fisik, Mekanik dan Aktifitas Antimikroba Film Edible Kitosan. Skripsi. Departemen Ilmu dan teknologi Pangan Fakultas Teknologi Pertanian Institut Pertanian Bogor

Sun, Sahomin, Y.Song, Q Zheng.2008. Thermo-molded wheat gluten plastic plasticized with gliserol:effect of molding temperature. J Food Hydrocoll 22:1006-1013

Xu, Y.X., K.M. Kim, M.A. Hanna, and D. Nag. 2005. Chitosan-starch composite film: preparation and characterization. Industrial Crops and Products 21: 185192. 